\title{
Seasonal Incidence of Gram Pod Borer Helicoverpa armiger (Hubner) on Prominent Varity of Sown Different Dates on Chickpea
}

\author{
Rishi Pal ${ }^{1}$, Rajendra Singh*², Y.P. Malik ${ }^{3}$ and Awaneesh Kumar ${ }^{4}$ \\ ${ }^{1}$ Biocontrol Laboratory, ${ }^{2 \& 4}$ Deptt. of Entomology, Sardar Vallabhbhai Patel University \\ of Agriculture and Technology, Meerut - 250110( UP), India \\ ${ }^{3}$ Linseed Unit, Deptt. of Entomology, Chandra Shekhar Azad University of Agriculture \\ and Technology, Kanpur (U.P.) India \\ *Email: singhrajendra0113@gmail.com
}

\begin{abstract}
Seasonal intensity of gram pod borer was noticed on four varieties sown as two different dates. First appearance of gram pod borer was recorded in $49^{\text {th }}$ standard week on December 9,2011 . There was no initial infestation of this pest on late sown (Nov. 18, 2011) varieties during $49^{\text {th }}$ standard weeks, but it appeared in subsequent weeks with its mild intensity ( $0.12-0.24$ larvae / $\mathrm{m}$ row) on different varieties. Conclusively, it can be inferred that temperature had played negative role on the intensity of gram pod borer, while relative humidity exhibited its positive impact on this pest on all the tested varieties of chickpea sown at different dates. Average temperature between $12.60-14.80{ }^{\circ} \mathrm{C}$ ( $\max .18 .0$ to $22.6^{\circ} \mathrm{C}$ and $\min .7 .2$ to $11.1^{\circ} \mathrm{C}$ ) and relative humidity 69.0 to $90 \%$ (max. $87-90$ and minimum 51-82\%) were found suitable for the multiplication of this pest during the cropping season. The evaporation pest population and $0.08-1.3 \mathrm{~mm} /$ day rate of evaporation found suitable for the pest multiplication. Wind velocity, sun shine and rainfall were the non significant weather parameter on gram pod borer in chickpea.
\end{abstract}

Key words: $H$. armigera Hubner, Chick pea, Pod borer, Pulses, Seasonal incidence.

Paper cited: Pal, R., Singh, R., Malik, Y.P. and Kumar, A. (2016). Seasonal Incidence of Gram Pod Borer Helicoverpa armiger (Hubner) on Prominent Varity of Sown Different Dates on Chickpea. South Asian Journal of Food Technology and Environment, 2(2): 399-407.

\section{Introduction}

Chickpeas (Cicer arietinum L.) are one of the oldest and most widely consumed legumes in the world, particularly in tropical and subtropical areas. It is also called as Ceci bean, Bengal gram, Garbanzo bean, Chana and Sanagalu bean. Chickpea is a versatile crop that is grown in almost every part of globe today. Some of the major producers of desi chickpea are India, Pakistan, Myanmar, Australia and Bangladesh, while the top producers of Kabuli chickpeas are Turkey, Iran, Spain, Canada, Syria, USA, Ethiopia, Tanzanzia, Tunisia, Sudan, Malawi and Portugal. India is the largest producer of chickpea followed by Pakistan, Turkey and Iran. In fact, about $70 \%$ of total world production of chickpeas is dominated by India. (Anon, 2011). India occupies first position in the world in terms of area (66\%) and production $(70 \%)$. The crop occupies 89.62 lakh hectare area with production of 74.0 lakh tonnes and $911 \mathrm{~kg} / \mathrm{ha}$ productivity. It is primarily grown in Madhya Pradesh, Rajasthan, Maharashtra, Uttar Pradesh, Andhra Pradesh and Karnataka, but on small scale in Orissa, Bihar, Gujrat, Tamil Nadu and Haryana also (Anon, 2011-12).

Abiotic and Biotic stresses are the major constraints in enhancing the productivity of chickpea in India. Insect pests and diseases are biotic bottlenecks in realizing its potential yield. To keep pace with the demand of ever increasing human population of the country, there is an urgent need to increase the production of chickpea. 
One of the most practical means of increasing chickpea production is to minimize losses caused by the biotic factors, which include insect-pests, diseases and weeds under field conditions. Chickpea faces the attack of more than 60 insect-pets right from germination to maturity (Srivastava et al, 2005). Among them, gram pod borer, Helicoverpa armigera (Hubner) is considered as key pest causing $29 \%$ yield losses in chickpea at national level. The yield losses in Uttar Pradesh have been recorded up to $14.6 \%$ with a range of 3.1 to $32.9 \%$ (Lal et al., 1985). This pest is highly polyphagous and has been reported to feed on more than 181 plant species belonging to 45 families, 40 dicots and 5 monocots (Manjunath et al., 1989). The young larvae feed on tender portion of the leaves and shoots by making scratches. Second instar and subsequent grown-up larvae consume whole leaf, leaf buds, flower buds, and flowers. Under Severe pest infestation, whole crop may get defoliated. On development of pods, the larvae make hole in the pods and move inside to feed on grains. A single larva is capable of destroying 30-40 pods in its larval period (Chaudhary and Chaudhary, 1975). At the same time adequate ecological data is prerequisite for integrated pest management, which can therefore be enhanced after determining the seasonal abundance. The knowledge on the seasonal incidence of pulse pod borer will certainly be helpful in formulating the insect pest management strategies for Helicoverpa armigera Hubner at Kanpur condition.

\section{Materials and Methods}

Intensity of Gram Pod borer: The investigations were carried out at Students Instructional Farm, C.S.A. University of Agriculture and Technology, Kanpur during rabi 2011-2012. The trial was sown on two sowing dates i.e. normal sowing $\left(3^{\text {rd }}\right.$ November, 2011) and late sowing (18 ${ }^{\text {th }}$ November, 2011) in main plots with factorial combinations of four varieties viz., KGD-
1168, KWR-108, Avarodhi and Udai with three row spacing like $30 \mathrm{~cm}, 40 \mathrm{~cm}$ and 50 $\mathrm{cm}$ plant spacing of about $10 \mathrm{~cm}$ was maintained by thinning in each plot. The foresaid varieties of chickpea were sown on two different dates at three row spicing. The experiment was executed in Split Plot Design with factorial combination in sub plot with three replications. Sowing dates were adjusted in main plot, whereas varieties and row spacing were taken in sub plots as factorial combinations. The experiment was laid out in $9.0 \mathrm{~m} \times 4.5 \mathrm{~m}$ plot size with block border of $1.5 \mathrm{~m}$ and $1.0 \mathrm{~m}$ plot border.

The experiment was kept under vigil for the initiation of incidence of gram pod borer (H. armigera) and total number of larvae of gram pod borer were counted in one meter row length selected randomly from three different rows in each replication at weekly intervals from the appearance of the pest as suggested by Saini and Jaglan (1998) and Ahmad and Rai (2005). Replication wise mean intensity of the larvae was calculated by averaging the population noticed in randomly selected three rows. Larval intensity of gram pod borer was recorded till the availability of the pest in the field. After completing the replication wise observations recorded at weekly intervals on the intensity of gram pod borer, general equilibrium position (GEP) of this pest was generated for each treatment by calculating the arithmetic mean of the observations recorded for studying the effect of various treatments. Weekly mean intensity of the pest was also computed for normal sown, late sown crop and irrespective of sowing date to observe the impact of weather parameters prevailing during the crop season.

Weather Parameter: Observations on daily weather parameters prevailing during the crop season were collected from the Department of Agronomy of the University, which was converted as per the standard weeks. 
Statistical analysis: Arithmetic means of all the weekly observations on the intensity of gram pod borer were calculated treatment wise, which were further averaged for computing the general equilibrium position (GEP) of the pest for the treatments. Simple correlation coefficient (r) values were determined between the intensity of gram pod borer recorded during vegetative phase and reproductive phase and full season on all four varieties sown at $40 \mathrm{~cm}$ row spacing with the prevailing weather parameters during the crop season. Data on GEP of pest intensity, pod damage and seed yield were analysed statistically for their critical differences using Split Plot Design with factorial combination in sub plot.

\section{Results and Discussion}

\section{Seasonal incidence of gram pod borer in chickpea}

Seasonal intensity of gram pod borer was noticed on four varieties i.e. KGD-1168, KWR-108, Avarodhi and Udai sown as two different dates viz. Nov.3, Nov. 18, 2011. These varieties were sown at recommended spacing $(40 \mathrm{~cm})$ in the experiment conducted for studying the effect of agronomic alternation on the intensity of gram pod borer in chickpea. Observations on gram pod borer intensity were recorded at weekly interval replication wise and their simple mean is presented in Table1.

First appearance of gram pod borer was recorded in $49^{\text {th }}$ standard week on December 9, 2011 with its initial intensity of $0.27,0.18,0.12$ and 0.15 larvae $/ \mathrm{m}$ row on chickpea varieties KGD-1168, KWR-108, Avarodhi and Udai sown Nov. 03, 2011, respectively. There was no initial infestation of this pest on late sown (Nov. 18, 2011) varieties during $49^{\text {th }}$ standard weeks, but it appeared in subsequent weeks with its mild intensity $(0.12-0.24$ larvae / $\mathrm{m}$ row) on different varieties. The intensity of gram pod borer increased in ensuring weeks and noticed above the economic threshold level of one larva $/ \mathrm{m}$ row length in the end of December (52th standard week). At this stage, there was $1.38,1.20,1.15$ and 1.21 larvae/m row observed on KGD-1168, KWR-108, Avarodhi and Udai Varieties sown at normal time (Nov. 03, 2011), respectively. During vegetative phase, maximum population of gram pod borer was noticed to be $1.73,1.61,1.27$ and 1.50 larvae/m row length on respective varieties in the first week of January, which could not show variation in pest intensity recorded on these varieties sown on second date of sowing. After this week, the intensity of this pest was observed in a declining trend for next two weeks in $3^{\text {rd }}$ standard week during January. In this week the intensity of gram pod borer was noticed to be $0.73,0.60,0.36$ and 0.49 larvae/m rows on the respective varieties sown at normal time (Nov. 03, 2011), which was below economic threshold level of this pest. However, the intensity of this pest being 1.17 , $1.09,0.68$ and 0.91 larvae/m row were noticed on KGD-1168, KWR-108, Avarodhi and Udai varieties sown under late condition. In the end of January, abrupt rise in pest intensity was recorded on the tested varieties, which was 2.72, 2.68, 1.94 and 3.0 larvae $/ \mathrm{m}$. row in first sowing date and $3.68,3.40,2.33$ and 3.70 larvae/m row on second date of sown varieties, respectively. This trend of increasing in pest intensity was continued till mid February i.e. $17^{\text {th }}$ standard week (Feb. 2, 2012).

In the middle of February maximum intensity of gram pod borer was observed to be $8.31,9.12,6.15$ and 8.85 larvae/m row in first date of sowing and 9.26, 9.07, 5.39 and 10.94 larvae $/ \mathrm{m}$ row in second sowing on chickpea varieties KGD-1168, KWR- 108, Avarodhi and Udai, respectively. At this stage the crop was in flowering and podding stage. Almost all the larvae of gram pod borer were seen to damaging either to flowers or pods of the crop. All the varieties sown at both dates harboured $>5$ larvae $/ \mathrm{m}$ row intensity of this pest in the $5^{\text {th }}$ week of February $\left(\right.$ Feb. 3, 2012) to $9^{\text {th }}$ standard week (March 2, 2012). There was 
sudden decline in the pest intensity during next two weeks irrespective of sowing time and varieties. In the middle of March, the pest intensity remained below one larvae/m row being $0.6,0.5,0.21$ and 0.27 in first date of sowing and $0.82,0.58,0.37$ and 0.52 larvae $/ \mathrm{m}$ row in second date of sowing on chickpea varieties KGD-1168, KWR-108, Avarodhi and Udai, respectively. However, there was no intensity of this pest recorded on the varieties sown at optimum time, while below 0.5 larvae/m row on these varieties sown late (Nov. 18, 2011). General equilibrium position (GEP) of gram pod borer for KGD-1168, KWR-108, Avarodhi and Udai varieties was calculated to be $2.71,2.55,2.02$ and 2.45 larvae/m row length for first date sowing, while it was 3.17, 2.99, 2.18 and 3.08 larvae/m row length in second date of sowing. This trend of pest infestation on different varieties sown at different dates exhibited that the crop sown under late condition was ore prepared than timely sown crop.

From the above narrated results on the seasonal intensity of gram pod borer, $H$. armigera on different varieties of chickpea sown under normal and late condition, it can be inferred that the pest appeared during second week of November on normal sown crop and in mid November on late sown crop with its intensity of $<1$ larvae/m row. The first peak in the intensity of this pest was observed during first week of January irrespective of sowing time, which declined there after till $3^{\text {rd }}$ week of January (Jan. 20, 2012). The pest increased continuously from the end of January to mid of February showing the second peak of intensity in the reproductive phase of crop. On the basis of general equilibrium position (GEP) of gram pod borer, it can be concluded that normal sown crop had lesser load of this pest than the late sown crop. These results on the seasonal intensity of gram pod borer on different varieties in similarity with those of Ravi and Verma (1997), They studied the seasonal incidence of $H$. armigera in relation to date of sowing in chickpea and reported that the incidence of $H$. armigera started in the first week of January and reached at its peak in March irrespective of date of sowing. Singh et al., (2005) studied that seasonal occurrence of larval population of $(H$. armigera Hubner) on chickpea in northwest Rajasthan. They reported that the larval population increased gradually until the first week of December then declined until the end of January. The population started to increase again from mid February until the second week of April and then declined abruptly. The first peak of larval population was recorded on the first week of December whereas the second peak was registered in the second week of April.

Views of Singh and Yadav (2006) also support these findings, who reported that larval activity of $H$. armigera continued throughout the crop season with two peaks in both year, i.e. the first from 45 to 49 standard weeks and the second from 5 to 13 standard weeks. The highest mean larval populations of 6.3 and 6.4 mean larvae $/ \mathrm{m}^{2}$ were observed in 45 and 12 standard week, respectively. The findings of Chatar et al., (2010) regarding the appearance of gram pod borer in chickpea from $2^{\text {nd }}$ week of December to $3^{\text {rd }}$ week of January and decline in population gradually towards the maturity of the crop, confirms the present studies.

\section{Relationship between intensity of gram pod borer and weather parameters}

Simple correlation coefficient values (r) were calculated between the intensity of gram pod borer and prevailing weather factors during the crop season, which have been presented in Table 2. Relationship of this pest with the weather parameters were developed for vegetative phase, reproductive phase and over all cropping season on different varieties.

It is evident from the data presented in Table-2: that temperature (maximum, minimum and average) showed negative relationship with intensity of gram pod borer 
noticed on all the tested varieties of chickpea sown on different dates. Maximum temperature play more important role for the multiplication of this pest during vegetative phase of the crop, as it showed non significant negative correlation ( $r$ ) values of -0.652 , $0.676,-0.629$ and -0.678 with the borer intensity noticed on KGD-1168, KWR-108, Avarodhi and Udai varieties sown at optimum time (Nov.3 2011), respectively. Similarly, the value of simple correlation coefficient were calculated to be $-0.723,-0.729, \quad-0.674$ and -0.719 for the respective varieties sown under late condition (Nov. 18, 2011). It is evident from data on seasonal intensity of gram pod borer on different varieties sown on different dates that first peak of intensity was recorded in first standard week of January during vegetative phase, while the second peak was obtained in February ( $7^{\text {th }}$ standard week) average temperature of 11.10 to $14.60^{\circ} \mathrm{C}$ (maximum $18-22.6^{\circ} \mathrm{C}$ and minimum 4.1 $11.1^{\circ} \mathrm{C}$ ) during vegetative phase of crop, while average temperature between $13.40-16.30^{\circ} \mathrm{C}$ (maximum $19.30-23.8^{\circ} \mathrm{C}$ and $\mathrm{Min} .8 .3-11.5^{\circ} \mathrm{C}$ ) during reproductive phase of the crop were found suitable for the best multiplication for this pest.

Relative humidity showed nonsignificant positive correlation with intensity of gram pod borer in chick pea exhibiting simple correlation coefficient (r) values of $0.701, \quad 0.733, \quad 0.623$ and 0.702 during vegetative phase in normal sown crop and $0.699,0.725,0.331$ and 0.699 in late sowing of KGD-1168, KWR-108, Avarodhi and Udai varieties of chickpea, respectively,. The impact of average relative humidity was found to reduce, as the correlation values ranged between 0.381 to 0.431 in timely planted crop and 0.416 to 0.453 in late sown chickpea varieties.

However, overall impact of relative humidity on the multiplication of pod borer was not very much prominent during this cropping season. During vegetative phase of the crop, average relative humidity ranging between 69-90 per cent (max. 94-98 min and 44-82\%) during vegetative phase and 65.50$73.50 \%$ (max. $85-91$ and $\min .46-56 \%$ ) during reproductive phase of crop was found responsible for the best multiplication of this pest. Wind velocity showed non-significant positive relationship during vegetative phase and negative association during reproductive phase of the crop. The evaporation rate had significant negative impact on the multiplication of this pest throughout the cropping season. It was more prominent during the vegetative phase of the crop, as it exhibited significant negative correlation value (r) of $-0.868,-0.868,-0.889$ and -0.890 for the varieties KGD-1168, KWR-108, Avarodhi and Udai sown at normal time, respectively, while the values were -0.916 , $0.902,-0.919$ and -0.917 for the respective varieties sown under late condition (Nov. 18, 2011). Sunshine hours did not show its impact in a set pattern on the intensity of this pest. Similarly the rainfall also did not play major role on the multiplication of this pest.

Conclusively, it can be inferred that temperature had played negative role on the intensity of gram pod borer, while relative humidity exhibited its positive impact on this pest on all the tested varieties of chickpea sown at different dates. Average temperature between $12.60-14.80{ }^{0} \mathrm{C}$ ( $\max .18 .0$ to $22.6^{\circ} \mathrm{C}$ and $\min .7 .2$ to $11.1^{\circ} \mathrm{C}$ ) and relative humidity 69.0 to $90 \%$ (max. $87-90$ and minimum 51-82\%) were found suitable for the multiplication of this pest during the cropping season. The evaporation pest population and $0.08-1.3 \mathrm{~mm} /$ day rate of evaporation found suitable for the pest multiplication. Wind velocity, sun shine and rainfall were the non significant weather parameter on gram pod borer in chickpea. Regarding the impact of weather parameters for the multiplication of this pest, the results are in accordance with Vaishampayan and Veda (1980), who reported minimum temperature between $10-14^{\circ} \mathrm{C}$ as most favorable for the development of gram pod borer in chickpea. Singh et al., (2005) and 
Singh and Yadav (2006) reported positive relationship of temperature with the intensity of gram pod borer in chickpea, which did not match with the present findings. However, the work of Chatar et al., (2010) regarding negative association of temperature and positive relationship of relative humidity with the larval population of gram pod borer provides full support to the present investigations. Impact of wind velocity, sunshine and rain fall on the multiplication of this pest in chickpea is in conformity with those of Reddy et al., (2009).

\section{Conclusion}

However, such high quantum in yield losses can be lowered by the adoption of improved technologies for its cultivation, which include the sowing of pest resistant/tolerant variety at optimum time supported with recommended agronomic manipulation and need based application of recommended insecticides. In recent years, gram pod borer has caused a serious threat to Indian agriculture in general and chickpea in particular due to the development of resistance towards commonly used insecticides like synthetic pyrethroids and other related problems pertaining to the ecosystem.

\section{References}

1. Ahmad, R. and Rai, A.B. (2005). 25 years of Research on Helicoverpa armigera at IIPR, India Institute of Pulses Research, Kanpur. Pp.54.

2. Annoymous, (2011-12). www.flipkart.com

3. Anonymous, (2011). Indore Global All right research powered by Jindal Tech. Ventures.

4. Anwar, M., Shafique, M., Ahmad, M. and Shakoori, A.R. (1992). Incidence of attack and population fluctuation of Helicoverpaarmigera Hubner in relation to chickpea phenology and environmental factors. Proceedings of Pakistan Congress Zoology, 12: 93.

5. Chatar, V.P., Raghvani, K.L., Joshi, M.D., Ghadge, S.M., Deshmukh, S.G.,
Dalave, S.K. (2010). Population dynamics of pod borer, Helicoverpaamigera (Hubner) infesting chickpea. International Journal of plant protection, 3(1): 65-67.

6. Chaudhary, J.P. and Chaudhary, S.D. (1975). Insect pests of gram and their control. Haryana Farming, 5: 27-28.

7. Lal, S.S., Sachan, J.N. and Yadav, C.P. (1985). Sex pheromone traps a novel tool for monitoring gram pod borer population. Plant Protection Bulletin, 37(3-4): 3-5.

8. Manjunath, T.M., Bhatnagar, V.S., Pawar, C.S. and Stianantham, S. (1989). Economic importance of Heliothis in India and assessment of their natural enemies and host plants. Proceeding of Workshop on Biological control of Heliothis increasing the effectiveness of natural enemies, (Eds. King, E.G. and Jackson, R.D.,) Far East Regional Office, USDA, New Delhi, (India). pp. 197-298.

9. Ravi, G. and Verma, S. (1997). Seasonal incidence of chickpea pod borer Helicoverpaarmigera Huber and its larval parasitoid on chickpea crop. Indian Journal of Entomology, 59(4): 359-361.

10. Reddy, V., Anandhi, P., Elamathi, S., Varma, S. (2009). Seasonal occurrence of pulse pod borer Helicoverpaarmigera (L.) on chick pea at Eastern U.P. region. Agricultural Science Digest, 29(2) 6062.

11. Saini, R.K. and Jaglan, R.S. (1998). Incidence of Helicoverpaarmigera Hubner in chickpea during different months. Annals of Agriculture Biosphere Research, 3(1): 101-103.

12. Singh, S.S. and Yadav, S.K. (2006). Evaluation of Chickpea varieties for their resistance against gram pod borer, Helicoverpaamigera. Indian Journal of Entomology, 68(4): 321-324.

13. Singh, S.S. and Yadav, S.K. (2006). Evaluation of Chickpea varieties for their resistance against gram pod borer, Helicoverpaamigera. Indian Journal of Entomology, 68(4): 321-324.

14. Singh, V., Singh, R.K. and Prakash. V. 2005. Seasonal occurrence of larval population of Helicoverpaarmigera Hubner on chickpea in north-west 
Rajasthan. Indian Journal of Pulses Research, 18(1): 92-93.

15. Srivastava, C.P., Ahmad, R., Ujagir, R. and Das, S.B. (2005).

Helicoverpaarmigera Hubner Management in Pulses Present scenario and future strategies, In: Recent Advances in Helicoverpa Management, (Eds. H. Saxena, A.B. Rai, R. Ahmad and Sanjeev Gupta), Indian Society of
Pulses Research and Development, Indian Institute of Pulses Research, Kanpur (India). pp. 265-286.

16. Vaishampayan, S.M. and Veda, O.P. (1980). Population dynamics of gram pod borer Heliothisarmigera (Hub.) and its outbreak situation on gram at Jabalpur. Indian Journal of Entomology, 42(3): 453-459. 
Table-1: Seasonal intensity of gram pod borer on different varieties of chickpea (larvae/m row)

\begin{tabular}{|c|c|c|c|c|c|c|c|c|c|c|c|c|c|c|c|c|c|c|}
\hline $\begin{array}{l}\text { Sowing } \\
\text { Date }\end{array}$ & Variety & \multicolumn{17}{|c|}{ Intensity of larvae (no./m row) on different dates } \\
\hline \multirow{2}{*}{$\begin{array}{l}\text { Nov. } \\
03,11\end{array}$} & $\begin{array}{l}\text { KWR } \\
108\end{array}$ & 0.18 & 0.24 & 0.61 & 1.20 & 1.61 & 1.33 & 0.60 & 2.68 & 4.85 & 6.30 & 9.12 & 5.29 & 4.75 & 1.60 & 0.50 & 0.00 & 2.55 \\
\hline & Udai & 0.15 & 0.20 & 0.63 & 1.21 & 1.50 & 1.26 & 0.49 & 3.00 & 4.44 & 6.00 & 8.85 & 5.15 & 4.80 & 1.33 & 0.27 & 0.00 & 2.45 \\
\hline \multirow{2}{*}{$\begin{array}{l}\text { Nov. } \\
18,11\end{array}$} & $\begin{array}{l}\text { KGD } \\
1168\end{array}$ & 0.00 & 0.24 & 0.71 & 1.38 & 1.73 & 1.54 & 1.17 & 3.68 & 7.00 & 6.80 & 9.26 & 7.61 & 5.80 & 2.47 & 0.82 & 0.65 & 3.17 \\
\hline & $\begin{array}{l}\text { KWR } \\
108\end{array}$ & 0.00 & 0.21 & 0.61 & 1.20 & 1.61 & 1.49 & 1.09 & 3.40 & 6.45 & 7.05 & 10.07 & 6.50 & 5.40 & 1.86 & 0.58 & 0.41 & 2.99 \\
\hline
\end{tabular}


South Asian J. Food Technol. Environ., 2(2): 399-407 (2016) ISSN 2394-5168(Print), 2454- 6445(online)

Table 2: Simple correlation coefficient ( $r$ ) between intensity of gram pod borer in different varieties of chickpea and weather parameters during 2011-12

\begin{tabular}{|c|c|c|c|c|c|c|c|c|c|c|c|c|}
\hline \multirow{2}{*}{ Sowing date } & \multirow{2}{*}{ Variety } & \multirow{2}{*}{ Crop stage } & \multicolumn{3}{|c|}{ Temperature $\left({ }^{0} \mathrm{C}\right)$} & \multicolumn{3}{|c|}{ Relative humidity (\%) } & \multirow{2}{*}{$\begin{array}{l}\text { Wind } \\
\text { velocity } \\
(\mathrm{km} / \mathbf{h r})\end{array}$} & \multirow{2}{*}{$\begin{array}{l}\text { Evaporation } \\
\text { rate }(\mathrm{mm} / \mathrm{day})\end{array}$} & \multirow{2}{*}{$\begin{array}{l}\text { Sun shine } \\
\text { (hrs/day) }\end{array}$} & \multirow{2}{*}{$\begin{array}{l}\text { Rainal } \\
(\mathbf{m m})\end{array}$} \\
\hline & & & Max. & Min. & Av. & Max. & Min. & Av. & & & & \\
\hline \multirow[t]{12}{*}{ Nov 3, 2011} & $\begin{array}{l}\text { KGD-1168 } \\
\text { (V1) }\end{array}$ & Vegetative & -0.652 & -0.058 & -0.458 & 0.094 & 0.706 & 0.701 & -0.287 & $-0.868^{*}$ & -0.711 & 0.610 \\
\hline & & Reprodutive & -0.308 & 0.405 & -0.357 & 0.489 & 0.241 & 0.388 & -0.289 & -0.525 & 0.007 & 0.316 \\
\hline & & Over all & 0.018 & -0.899 & -0.029 & -0.009 & -0.061 & -0.042 & 0.141 & -0.315 & 0.250 & 0.286 \\
\hline & $\begin{array}{l}\text { KWR-108 } \\
\text { (V2) }\end{array}$ & Vegetative & -0.676 & -0.036 & -0.461 & 0.060 & 0.746 & 0.733 & 0.333 & $-0.868 *$ & -0.748 & 0.601 \\
\hline & & Reprodutive & -0.337 & -0.409 & -0.375 & 0.483 & 0.248 & 0.381 & -0.341 & -0.545 & -0.093 & 0.322 \\
\hline & & Over all & -0.013 & -0.101 & -0.053 & 0.03 & -0.049 & -0.029 & 0.092 & -0.339 & 0.181 & 0.292 \\
\hline & $\begin{array}{l}\text { Avarodhi } \\
\text { (V3) }\end{array}$ & Vegetative & -0.629 & -0.169 & -0.506 & 0.171 & 0.611 & 0.623 & 0.123 & $-0.889^{*}$ & -0.632 & 0.564 \\
\hline & & Reprodutive & -0.321 & -0.401 & -0.362 & 0.531 & 0.293 & 0.431 & -0.288 & -0.549 & -0.023 & 0.371 \\
\hline & & Over all & -0.012 & -0.115 & -0.059 & 0.053 & -0.031 & 0.006 & 0.101 & -0.353 & 0.217 & 0.331 \\
\hline & Udai (V4) & Vegetative & -0.678 & -0.098 & -0.498 & 0.067 & 0.712 & 0.702 & 0.261 & $-0.890 *$ & -0.722 & 0.571 \\
\hline & & Reprodutive & -0.34 & -0.417 & -0.381 & 0.490 & 0.264 & 0.395 & -0.331 & -0.552 & -0.061 & 0.309 \\
\hline & & Over all & -0.018 & -0.114 & -0.063 & 0.014 & 0.043 & -0.020 & 0.093 & -0.348 & 0.193 & 0.281 \\
\hline \multirow[t]{12}{*}{ Nov. 18, 2011} & $\begin{array}{l}\text { KGD-1168 } \\
\text { (V1) }\end{array}$ & Vegetative & -0.273 & -0.145 & -0.554 & 0.036 & 0.714 & 0.699 & 0.293 & $-0.916^{*}$ & -0.725 & 0.541 \\
\hline & & Reprodutive & -0.301 & -0.432 & -0.370 & 0.536 & 0.27 & 0.421 & -0.335 & -0.547 & 0.009 & 0.253 \\
\hline & & Over all & 0.052 & -0.078 & -0.004 & -0.039 & -0.086 & -0.072 & 0.163 & -0.301 & 0.286 & 0.227 \\
\hline & $\begin{array}{l}\text { KWR-108 } \\
\text { (V2) }\end{array}$ & Vegetative & -0.729 & -0.103 & -0.534 & -0.003 & 0741 & 0.725 & 0.354 & $-0.902 *$ & -0.754 & 0.547 \\
\hline & & Reprodutive & -0.356 & -0.444 & -0.402 & 0.525 & 0.285 & 0.424 & -0.367 & -0.572 & -0.094 & 0.296 \\
\hline & & Over all & 0.005 & -0.100 & -0.042 & -0.016 & -0.061 & -0.046 & 0.117 & -0.333 & 0.213 & 0.261 \\
\hline & $\begin{array}{l}\text { Avarodhi } \\
\text { (V3) }\end{array}$ & Vegetative & -0.674 & -0.210 & -0.551 & 0.138 & 0.625 & 0.331 & 0.137 & $0.919^{* *}$ & -0.649 & 0.532 \\
\hline & & Reprodutive & -0.345 & -0.452 & -0.399 & 0.549 & 0.317 & 0.453 & -0.292 & -0.554 & 0.023 & 0.405 \\
\hline & & Over all & 0.009 & -0.116 & -0.047 & 0.005 & -0.051 & -0.021 & 0.158 & -0.328 & 0.276 & 0.344 \\
\hline & Udai (V4) & Vegetative & -0.719 & -0.149 & -0.554 & 0.033 & 0.716 & 0.699 & 0.276 & $0.917^{*}$ & -0.728 & 0.530 \\
\hline & & Reprodutive & -0.356 & -0.431 & -0.396 & 0.516 & 0.279 & 0.416 & -0.356 & 0.570 & -0.096 & 0.324 \\
\hline & & Over all & 0.005 & -0.101 & -0.043 & -0.011 & -0.070 & -0.049 & 0.112 & -0.332 & 0.213 & 0.279 \\
\hline
\end{tabular}

N.B. $* \& * *$ Significant at $5 \%$ and $1 \%$ level of significance 